\title{
Review of Foreign Direct Investment in Jordan
}

\author{
Manuel Fernandez, Odai Mohannad Suleiman, and Sereen Najati Yaseen
}

\begin{abstract}
Globalization has made worldwide mobility of money extremely easy. The investors prefer to invest in places that offer attractive returns and are relatively less risky. The inflow of FDI gives developing countries access to capital that would otherwise not be available. FDI also provides much needed foreign exchange and therefore helps to adjust some of the macroeconomic imbalances in developing countries. Jordan is in the growth mode, but the resources available is limited and very often insufficient, hence they are also in the race to attract international investments. The main objectives of this study are to find out the status of Jordan as a destination for FDI, the factors that attracts FDI into Jordan, and the factors that hinder the flow of FDI into Jordan. This study is based on secondary data and covers a period of five years. The study analysis various determinants of FDI like market size, economic growth, infrastructure, political risk, corruption, labor market, raw materials, technological readiness, innovation, financial system, taxation, cost of capital and ease of doing business. The study reveals that Jordan's position in the global FDI map is on the decline and most of its rankings by global agencies are dropping year after year.
\end{abstract}

Index Terms - Foreign Direct Investment; Investor-friendly Environment; Transnational Corporations.

\section{INTRODUCTION}

Foreign direct investment (FDI) is generally made in open markets that provide the investor with a skilled workforce and above-average growth opportunities, rather than strictly regulated economies. FDI includes much more than a capital investment, it may also contain leadership, technology, knowhow, etc. There is a huge flow of investment between countries, investments flowing to locations that are comparatively more favorable than others. Investors will invest in assets that yield higher returns and are comparatively less risky. Each asset, company, or country has different characteristics at various times, which lure various investors differently [1].

Foreign direct investment (FDI) takes place when an organization in one country creates a business venture in another country, by setting up a new completely owned subsidiary, or purchasing a local business, or establishing a partnership in the foreign economy. Foreign direct investment that flows to developing economies generally takes four different forms: extractive industry FDI; infrastructure FDI; manufacturing and assembly FDI; and service FDI. Everyone has distinctive contributions to the growth and welfare of the host country. Each investment provides the host nation development and welfare with distinctive dangers or harmful threats. Moreover, the investment provides the host authorities with distinctive policy problems, enhancing valuable contributions and mitigating or preventing potential damage.

Jordan is an Arab country located in southwest Asia in the middle of the Middle East, in the southern part of the Levant and the northern part of the Arabian Peninsula. Jordan is bordered by many Arab countries, namely Syria, Iraq, Saudi Arabia, and Palestine. The population of Jordan in 2020 is approximately 10.5 million people. GDP for Jordan in 2019 was US $\$ 10.407$ billion. Table 1 gives the data on the inflow of FDI into Jordan during the period 2013 to 2019.

\begin{tabular}{cccc}
\multicolumn{4}{c}{ TABLE 1. FDI INFLOW TO JORDAN: (US\$ IN MILLION) } \\
\hline Year & Net inflows & Increase & Y-O-Y Growth \\
\hline 2013 & $1,946.8$ & 398.5 & $25.7 \%$ \\
\hline 2014 & $2,178.5$ & 231.7 & $11.9 \%$ \\
\hline 2015 & $1,600.3$ & -578.2 & $-26.5 \%$ \\
\hline 2016 & $1,553.0$ & -47.3 & $-3.0 \%$ \\
\hline 2017 & $2,029.7$ & 476.7 & $30.7 \%$ \\
\hline 2018 & 949.9 & $-1,079.8$ & $-53.2 \%$ \\
\hline 2019 & 915.8 & -34.1 & $-3.6 \%$ \\
\hline
\end{tabular}

Source: [2]

The inflow of FDI is observed to be decreasing, except in 2017, when there was a substantial growth, but the next year the decline was very drastic [2]. This scenario has prompted this study.

The main objectives of this study are to find out the status of Jordan as a destination for FDI, the factors that attract FDI into Jordan and the factors that hinder the flow of FDI into Jordan. The findings of the study would help the investors to arrive at a better decision regarding FDI into Jordan, and similarly help the regulators and other stakeholders to formulate appropriate policies and take necessary steps to enhance the FDI attractiveness of Jordan. This paper is organized as follows: Section 2 presents a literature review on FDI. Section 3 states the methodology. Section 4 focusses on analysis and discussions, and Section 5 concludes the paper.

Published on July 18, 2020.

Manuel Fernandez, Skyline University College, UAE.

(corresponding e-mail: qln_manuel@yahoo.com)

Odai Mohannad Suleiman, Skyline University College, UAE.

(e-mail: odaibataineh91@ gmail.com)

Sereen Najati Yaseen, Skyline University College, UAE.

(e-mail: sereen7689@gmail.com). 


\section{LITERATURE REVIEW}

Foreign direct investment is widely perceived as a powerful development engine for many receiving (host) countries. Virtually all countries are actively seeking to attract FDI, because of its expected favorable effect on income generation from capital inflows, advanced technology, management skills and market know-how [3]. The study by Oudat, Alsmadi and Alrawashdeh [4], investigated the long and short term elasticities between gross domestic product and FDI in Jordan. The study uses annual data to analyze the relationship between FDI and economic growth for the 1992-2013 period, and the results showed that there are long and short-term elasticities in FDI and GDP. The study by Alsmadi and Oudat [5] analyzed the relationship between FDI and financial development in Bahrain during the period $1978-2015$ by taking into consideration political conflicts that happened in the Middle East region: 'the Arab Spring'. An Autoregressive Distributed Lags Approach (ARDL) was used to analyze the data. The results of this study showed a positive relationship between financial development and FDI in the short and long run. The motivational factors such as natural resources, market resources, strategic resources, efficiency resources, locational advantages, etc., influenced Multinational Enterprises (MNEs) to perform various activities in the host countries. Initially MNEs search for the customers in host countries and conclude by encompassing productive activities when foreign market confers higher value to the firm [6].

Numerous studies have been conducted in different parts of the world and majority of the studies have inspected the effects of determinants of FDI inflow and found that relevant determinants include the size and growth potential of the host market, economic stability, economic growth, infrastructure, human capital, interest rate, per capita income, exchange rate, wage rate, quality of institutions, etc. The presentation of the literature review is sequenced in such a manner that the literature relating to market size is presented first, followed by political stability and then all literature relating to all other factors are presented subsequently.

Market size is expected to have a positive relationship with FDI. Market-oriented FDI aims to set up enterprises to supply goods and services to the local market. The general implication is that host countries with larger market size, faster economic growth and a higher degree of economic development will provide more and better opportunities for these industries to exploit their ownership advantages and therefore, will attract more market-oriented FDI [7]. Xaypanya, Rangkakulnuwat, and Paweenawat [8] investigated the significant factors determining foreign direct in Cambodia, Laos, and Vietnam (ASEAN3) and Indonesia, Malaysia, the Philippines, Thailand, and Singapore (ASEAN5), and found that market size and infrastructure facility are significant factors to attract FDI. Khachoo and Khan [9] conducted a study to examine the determinants of FDI in 32 developing countries from 1982 to 2008 using an econometric model. Their empirical results showed that market size, total reserve, and infrastructure were positively related to FDI inflows. Thus, one may deduce that large host countries with high growth rate and higher per capita income attract higher foreign direct investment due to larger potential demand.
Political stability and reliability determine the FDI inflows. Transnational Corporations (TNCs) prefer stable government so that their investment is protected. Political instability may be in the form of the negative attitude of the government towards TNCs, non-allowance of fund transfer, currency convertibility, war, bureaucracy and corruption. Political stability can also be measured by the number of changes of democratically elected governments [10]. The study by Root and Ahmed [11], Schneider and Frey [12], looking at aggregate investment flows into developing economies found that political instability significantly affects FDI inflows.

Tax policies including corporate and personal tax rates influence inward FDI. Other things being equal a country with lower tax rates should stand a greater chance of attracting FDI projects than a country with higher rates [13]. According to Neumayer and Indra [14], availability of raw materials provides investors with an added advantage with regards to producing efficiently. According to Milner [15], the presence of a productive labor force is one of the determinants that influence the scope of FDI in a country.

In brief, the trend in FDI flows differs by region and country. Although FDI has innumerable effects on the economy of host countries and most countries are trying hard to attract FDI, the inflow of FDI continues to be uneven, with some countries getting the lion's share and others barely getting any.

\section{METhODOLOGY}

The main objectives of this study are to find out the status of Jordan as a destination for FDI, the factors that attract FDI into Jordan, and the factors that hinder the flow of FDI into Jordan. The study is solely based on secondary data collected from local, regional and international agencies like Government of Jordan, Central Bank of Jordan, World Economic Forum, International Monetary Fund, Transparency International, World Bank group, United Nations and various publications of the statistical departments, governments, and the press. The study covers a period of five years from 2014-2015 to 2018-2019. The collected data are tabulated and analyzed using appropriate analytical tools.

\section{ANALYSIS AND DisCUSSIONS}

\section{A. Competitiveness}

The Global Competitiveness Reports published by the World Economic Forum assesses the competitiveness landscape of economies, providing insight into the drivers of their productivity and prosperity [16]. The IMD's rankings, which started in 1989, assess economies on hundreds of indicators: a combination of hard data, such as employment, cost of living, and government spending, and soft data from surveys of international business executives on topics including political stability and protection of intellectual property rights. The Report series remains the most comprehensive assessment of national competitiveness worldwide. Table 2 presents the year-wise ranking of Jordan by global competitiveness index for the year 2014 to 2019 . 
TABLE 2. COMPETITIVENESS RANKING: JORDAN - 2014 TO 2019

\begin{tabular}{lcccccc}
\hline Year & 2014 & 2015 & 2016 & 2017 & 2018 & 2019 \\
\hline Global Rank & 64 & 64 & 63 & 65 & 73 & 70
\end{tabular}

Source: Compiled from Global competitiveness reports 2014 to 2019.

The data in Table 2 shows the relative ranking of Jordan has declined from rank 64 in the year 2014 to rank 70 in the year 2019, which could be either Jordan is going back in competitiveness or that other countries are enhancing their competitiveness at an accelerated pace and leaping forward which is pushing Jordan back in the relative ranking. This calls for an analysis of various determinants of FDI beginning with market size.

\section{B. Market Size}

Market size, growth in market size and market efficiency are important determinants of FDI. The market size and the growth prospects of the market of the host country are important pull factors and are positively related to the level of FDI flows [17], [18]. A huge market size allows the attainment of economies of scale, and transaction costs are lower in countries with higher levels of economic development [19], [20]. The population of Jordan in 2020 is approximately 10.5 million, the GDP is US $\$ 44.363$ billion and GDP per capita income is US\$ 4,541 according to the International Monetary Fund, World Economic Outlook Database [21]. The market size can be measured by the population and the growth of population of the country. A larger population means a better domestic market that can consume goods and services provided by investors. Table 3 gives the global ranking for Jordan on market size for the period 2014 to 2019 .

TABLE 3. MARKET SIZE: RANKING OF JORDAN - 2014 TO 2019

\begin{tabular}{lcccccc}
\hline Year & 2014 & 2015 & 2016 & 2017 & 2018 & 2019 \\
\hline $\begin{array}{l}\text { Global } \\
\text { Rank }\end{array}$ & 88 & 76 & 75 & 76 & 81 & 80 \\
\hline $\begin{array}{l}\text { Population } \\
\text { in Millions }\end{array}$ & 8.809 & 9.159 & 9.456 & 9.702 & 9.904 & 10.070 \\
\hline
\end{tabular}

Source: Compiled from Global competitiveness reports \& IMF

During the period of study Jordan's position has improved marginally from rank 88 in 2014 to 80 in 2019. The population has grown from 8.809 million in 2014 to 10.07 million in 2019; an appreciable increase of more than $14 \%$. But it is still a small market which on its own may not be attractive for foreign investors.

\section{Economic Growth}

Over the past decade, growth in advanced economies has been very weak. Many emerging economies - including Argentina, Brazil, Russia, India and China - are experiencing some slowdown or stagnation. In least-developed economies, growth remains well below potential and highly volatile. Productivity growth started slowing down well before the financial crisis of 2008. Between 2000 and 2007, total factor productivity (TFP) annual growth averaged just $1 \%$ in advanced economies and $2.8 \%$ in emerging and developing economies. TFP then plummeted during the crisis. Between 2011 and 2016, TFP grew by $0.3 \%$ in advanced economies and $1.3 \%$ in emerging and developing economies [22].
Corporates do not operate in vacuum, they are highly influenced and attracted by the environmental factors and economic growth of the economy in which they do business. Corporates in high growth economies can envisage to grow at a higher rate than those in the low growth countries as the environment highly influences the entity [23]. Table 4 shows the annual percentage growth rate of GDP at market prices based on constant local currency, for Jordan during the period 2014 to 2018.

TABLE 4. ECONOMIC GROWTH OF JORDAN - 2014 TO 2018

\begin{tabular}{lcccccc}
\hline Year & 2014 & 2015 & 2016 & 2017 & 2018 & Average \\
\hline Growth rate & $3.10 \%$ & $2.39 \%$ & $2 \%$ & $2.12 \%$ & $1.94 \%$ & $2.31 \%$ \\
\hline Global Rank & 96 & 117 & 130 & 130 & 132 & \\
\hline
\end{tabular}

Source: Compiled from The GlobalEconomy.com, reports 2014 to 2018

The global average growth rate for 2018 was $3.31 \%$ [24], but Jordan's was much lower at $1.94 \%$. During the last five years Jordan was growing at an annual average rate of $2.31 \%$, which is lower than the global average. Moreover, currently the global growth is slowing amid sluggish investment and weakening trade, which would further weaken the position of Jordan, making it lesser attractive for FDI.

\section{Infrastructure}

Infrastructure is a major determinant of FDI. Excellent infrastructure plays a major role in the productivity and profitability of Transnational Corporations, and thus, their decision about FDI location. Table 5 gives the global ranking of Jordan for the period 2014 to 2019 based on road connectivity, quality of road infrastructure, railroad density, efficiency of train services, airport connectivity, efficiency of air transport services, liner shipping connectivity, efficiency of seaport services, utility infrastructure, electricity access, electricity supply quality, exposure to unsafe drinking water and reliability of water supply.

TABLE 5. INFRASTRUCTURE RANKING: JORDAN - 2014 TO 2019

\begin{tabular}{lcccccc}
\hline Year & 2014 & 2015 & 2016 & 2017 & 2018 & 2019 \\
\hline Global Rank & 71 & 70 & 56 & 58 & 73 & 74 \\
\hline
\end{tabular}

Source: Compiled from Global competitiveness reports 2013-2014 to 2019

Infrastructure sector is a key driver for the economy. The infrastructure developments seem to be insufficient and Jordan is ranked 74 in the Global competitiveness report, 2019 , whereas it had a better ranking of 56 in 2016. For getting a clearer picture a probe is made into the Logistics Performance Index [25].

Logistics is the backbone of trade, and good logistics can reduce trade cost and make countries compete globally. Getting logistics right, means improving infrastructure, skills, customs and regulations, policies and governance at the right proportion. The Logistics Performance Index (LPI) is reported by the World Bank once in every two years, based on qualitative and quantitative data on six core performance components: (1) The efficiency of customs and border clearance, (2) The quality of trade and transport 
infrastructure, (3) The ease of arranging competitively priced shipments, (4) The competence and quality of logistics services, (5) The ability to track and trace consignments, (6) The frequency with which shipments reach consignees within scheduled or expected delivery times. Table 6 gives the ranking of Jordan for the period 2014 to 2018.

TABLE 6. LOGISTICS PERFORMANCE: RANKING OF JORDAN

\begin{tabular}{|c|c|c|c|c|c|c|c|}
\hline \multirow[b]{2}{*}{ Year } & \multirow[b]{2}{*}{$\begin{array}{c}\text { LPI } \\
\text { Global } \\
\text { Rank }\end{array}$} & \multicolumn{6}{|c|}{ Parameter-wise Global Ranks } \\
\hline & & 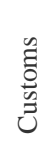 & 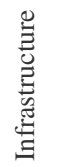 & 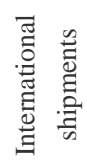 & 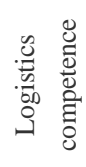 & 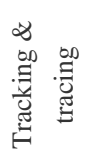 & $\begin{array}{l}\stackrel{\mathscr{\vartheta}}{\Xi} \\
: \Xi \\
: \Xi\end{array}$ \\
\hline 2014 & 68 & 78 & 76 & 65 & 60 & 93 & 58 \\
\hline 2016 & 67 & 83 & 62 & 49 & 61 & 62 & 71 \\
\hline 2018 & 84 & 88 & 70 & 119 & 93 & 84 & 76 \\
\hline
\end{tabular}

Source: Logistics Performance Index, 2014 - 2018

Jordan's ranking in the Logistics Performance Index has worsened from 68 in 2014 to 84 in 2018. Decline is seen in all the six pillars, the worst being in the international shipments and logistics competence. The position of Jordan among the emerging markets is at rank 17 according to the Agility Emerging Markets Logistics Index, 2020 [26].

\section{E. Productive Labor Market}

The vibrant diversified labor force attracts foreign direct investments. When international investors look for an investment destination, considerations about the skilled nature of the labor force is a matter of priority that determines their scope of success in a country [27]. Table 7 gives the data for the labor force which comprises people with ages 15 and older who supply labor for the production of goods and services during the period of study. It includes people who are currently employed and people who are unemployed but seeking work as well as first-time job-seekers.

TABLE 7. LABOR FORCE IN JORDAN - 2014 TO 2018

\begin{tabular}{lcccccc}
\hline Year & 2014 & 2015 & 2016 & 2017 & 2018 & 2019 \\
\hline Labor Force (million) & 2.23 & 2.33 & 2.43 & 2.51 & 2.57 & 2.63 \\
\hline Global Rank & 118 & 118 & 116 & 115 & 115 & 115 \\
\hline
\end{tabular}

Source: Compiled from TheGlobalEconomy.com reports 2014 to 2018

In 2019 the labor force in Jordan was 2.63 million. Throughout the period of study Jordan was having a very low positions between 115 and 118 . Now let us look at the labor market efficiency, Table 8 gives the ranking for Jordan on labor market efficiency during 2014 to 2019 based on cooperation in labor-employer relations, flexibility of wage determination, hiring and firing practices, redundancy costs, active labor market polices, workers' rights, ease of hiring foreign labor, internal labor mobility, effect of taxation on incentives to work, pay and productivity, reliance on professional management, and the ratio of women in labor force.
TABLE 8. LABOR MARKET EFFICIENCY: RANKING OF JORDAN

\begin{tabular}{lcccccc}
\hline Year & 2014 & 2015 & 2016 & 2017 & 2018 & 2019 \\
\hline Global Rank & 94 & 93 & 87 & 90 & 91 & 84 \\
\hline
\end{tabular}

Source: Compiled from Global competitiveness reports 2014 to 2019

An efficient labor market, easy availability of skilled labor, the ready availability of training facility and capacity to attract and retain right talent from within the country and other parts of the globe are the most important factors that attract international investors. Jordan is ranked 84 out of 141 nations ranked which is quite appreciable. There is still plenty of room for improvements, Jordan may have to look into its education and training system and ensure that the students graduating out of their higher education institutions have the knowledge and skills matching their peers graduating out of globally high ranked universities, and that the training institutions in Jordan are providing trainings that are globally the best.

\section{F. Political Risk}

Jordan has high degree of political stability among the counties in the Middle East, built around King Abdullah, who remains very popular and has the support of the army. TNCs usually assess political risk before investing in any country. There are many forms of political risks, but the extreme form is the possibility that the host country will take over a subsidiary. However, this form of political risk is an extreme case and not very common in today's global world. The more common forms of political risk include the negative attitude of the host government to TNCs, blockage of fund transfer, currency inconvertibility, war, bureaucracy, and corruption. Credendo Group [28] provides business and economic data for 200 countries and have classified country risk under different indicators like political risk short term, political risk medium/long term, special transactions risk, transfer risk, expropriation risk and political violence risk; under each of these indicators countries are classified into seven categories: from 1 (low risk) to 7 (high risk); among them the last three are related to direct investments, and let us probe into that:

Transfer Risk: The currency inconvertibility and transfer restriction risk refers to the inability to convert and transfer out of the host country any funds related to the investment. The average value for Jordan during the period of study is 5 for each year from 2014 to 2018, and in 2019 it has increased to 6. Which indicates that currency inconvertibility and transfer restriction risk is quite high for Jordan.

Expropriation Risk: The risk of expropriation encompasses all discriminatory measures taken by a host government which deprive the investor of its investment without any adequate compensation; and also includes events of embargo, change of (legal) regime and denial of justice, and the probability of a negative change in attitude towards foreign investments. The average value for Jordan during the period of study is 3 for each year from 2014 to 2019, which indicates that expropriation risk is low.

Political Violence Risk: Political violence includes all violent act(s) undertaken with a political objective; and includes: terrorism (political, religious and ideological 
objectives) and political violence damage (damage to material assets as a result of political violence); business interruption as a result of political violence damage. In order to assess the political violence risk, the index looks at the actual levels of internal violence in and external conflict with a country, but also at the conflict potential that arises from (lingering) internal and external tensions, frustration and dissatisfaction. The value for Jordan during the period of study is 4 , which indicates that the political violence risk is average for Jordan. Table 9 gives the consolidated ranking for the period 2014 to 2019 .

TABLE 9. COUNTRY RISK: RANKING OF JORDAN - 2014 TO 2019

\begin{tabular}{lcccccc}
\hline Year & 2014 & 2015 & 2016 & 2017 & 2018 & 2019 \\
\hline Transfer risk & 5 & 5 & 5 & 5 & 5 & 6 \\
\hline Expropriation risk & 3 & 3 & 3 & 3 & 3 & 3 \\
\hline Political violence risk & 3 & 4 & 4 & 4 & 4 & 4 \\
\hline
\end{tabular}

Source: Compiled from Credendo Group index reports 2014 to 2019

The international investors have to be quite cautious while venturing into Jordan. Now let us go for a deeper look into the levels of corruption in Jordan.

Corruption: Corruption distorts competition and investment and hinders free and fair trade. Corruption makes dealing with government officials, for example, to obtain local licenses and permits, less transparent and costlier, particularly for foreign investors. In this case, having a local partner lowers the transaction cost, such as the cost of securing local permits. At the same time sharing ownership may lead to technology leakage. Both costs of local permits and losses from technology leakage are positively related to the extent of corruption in a host country.

When corruption level is sufficiently high no investment will take place. Transparency International [29] has published the Corruption Perceptions Index (CPI) since 1995, annually ranking countries by their perceived levels of corruption, as determined by expert assessments and opinion surveys. The CPI generally defines corruption as 'the misuse of public power for private benefit.' Table 10 displays the ranks assigned to Jordan during the last six years.

TABLE 10. CORRUPTION: RANKING OF JORDAN - 2014 TO 2018

\begin{tabular}{lcccccc}
\hline Year & 2014 & 2015 & 2016 & 2017 & 2018 & 2019 \\
\hline Global Rank & 55 & 45 & 57 & 59 & 58 & 60 \\
\hline
\end{tabular}

Source: Compiled from Corruption Perceptions Index 2041 to 2018

The ranking by the Corruption Perceptions Index shows that the nation has to improve a lot in containing and controlling corruption, the data in the table shows that the position has declined from 55 in 2014 to 60 in 2019. Decision makers in Jordan must combat all types of corruption and reengineer government institutions to be agile and able to deal with conditions and changes and enact laws and legislation that stimulate investment.

\section{G. Interest Rates}

High interest rates tend to slow the growth of an economy and reduce the demand for the TNC's products and thus can negatively impact the flow of FDI. High loan interests translate into cost burden of a company and have been evidenced by the companies that decide to halt operations and move to other regions with low interest rates. From the perspective of an investor, low interest rates are better as compared to high rates because returns are high when the interest charges are low. Reduction of interest on loans is being introduced by the government of many countries for the purpose of creating an ideal environment for both domestic and international investments. Destinations with such incentives are bound to attract more investors than destinations with high interest rates.

Lending rate is the bank rate that usually meets the shortand medium-term financing needs of the private sector. This rate is normally differentiated according to creditworthiness of borrowers and objectives of financing. Table 11 gives the lending interest rates in Jordan during the period 2014 to 2018

TABLE 11. LENDING INTEREST RATES IN JORDAN - 2014 TO 2018

\begin{tabular}{lccccc}
\hline Year & 2014 & 2015 & 2016 & 2017 & 2018 \\
\hline Interest Rate & $8.99 \%$ & $8.48 \%$ & $8.11 \%$ & $8.39 \%$ & $8.66 \%$ \\
\hline Global Rank & 73 & 75 & 77 & 67 & 59 \\
\hline
\end{tabular}

Source: Compiled from TheGlobalEconomy.com reports 2014 to 2018

The global average lending interest rates for 2018 was $11.41 \%$. The lending rate in Jordan is lower than the global average and it was decreasing from 2014 to 2016, but since then it is increasing, which is not a good sign. Now let us probe into the financial system of Jordan.

The banking sector in Jordan is considered one of the main pillars of the Jordanian economy. Despite the difficult geopolitical situation, the sector is well capitalized and regulated which makes it a resilient and promising sector. The sector consists of 25 banks, 15 of which are listed on the Amman Stock Exchange (ASE). The total assets of the banking sector are equivalent to $180 \%$ of GDP [30]. Table 12 gives the ranking for Financial System of Jordan 2014 to 2019 based on the availability of domestic credit to private sector, financing of SMEs, venture capital availability, market capitalization, insurance premium, soundness of banks, non-performing loans as percentage of loan portfolio value, credit gap and banks' regulatory capital ratio.

Table 12. FINANCIAL SYSTEM RANKING: JORDAN - 2014 TO 2019

\begin{tabular}{lcccccc}
\hline Year & 2014 & 2015 & 2016 & 2017 & 2018 & 2019 \\
\hline Global Rank & 66 & 71 & 68 & 70 & 32 & 33 \\
\hline
\end{tabular}

Source: Compiled from Global competitiveness reports 2014 to 2019

The rank of Jordan has improved quite appreciably during the recent past, but there is room for plenty of improvements to strengthen the financial system.

\section{H. Tax Rates and Clarity of Taxation Policies}

Lower tax will give corporates and individuals more aftertax income that could enhance the wealth of the corporates, and individuals could use for buying more goods and services, or for saving. Investors prefer lower-tax locations 
to locate or relocate their businesses. Table 13 gives the corporate tax rates for Jordan, and the global and Asian averages.

TABLE 13. CORPORATE TAX RATES (IN \%) - 2014 TO 2019

\begin{tabular}{lcccccc}
\hline Year & 2014 & 2015 & 2016 & 2017 & 2018 & 2019 \\
\hline Jordan & 14 & 20 & 20 & 20 & 20 & 20 \\
\hline Asia average & 22 & 21.98 & 21.41 & 21.08 & 21.21 & 21.09 \\
\hline Global average & 23.88 & 23.77 & 23.62 & 24.06 & 24.02 & 23.79 \\
\hline
\end{tabular}

Source: Compiled from KPMG data

During the period of study, the corporate tax rates in Jordan is one of the lowest, and is lower than the Asian and global average [31]. This is a factor which can attract FDI into Jordan. Table 14 gives the individual income tax rates in Jordan, and the global and Asian averages.

TABLE 14. INCOME TAX RATES (IN \%) - 2014 TO 2019

\begin{tabular}{lcccccc}
\hline Year & 2014 & 2015 & 2016 & 2017 & 2018 & 2019 \\
\hline Jordan & 14 & 14 & 14 & 20 & 20 & 30 \\
\hline Asia average & 27.2 & 27.09 & 27.35 & 27.65 & 27.67 & 27.99 \\
\hline Global average & 31.08 & 30.8 & 30.97 & 31.41 & 31.39 & 31.23 \\
\hline
\end{tabular}

Source: Compiled from KPMG data

The individual income tax rates are increasing in Jordan, even though the rates are lower than the Asian and global average [32]. But this increasing income tax will hinder the flow of FDI into the country. Lower income tax reduces the cost of running a business, because at the time of salary negotiations the prospective employee looks at the after-tax annual pay package offered. The country will have to carry out reforms in the taxation policy to attract highly talented and skilled workforce needed for the domestic and MNCs operating in the country.

\section{Geographical Location}

Jordan is an Arab country located in southwest Asia in the middle of the Middle East, in the southern part of the Levant and the northern part of the Arabian Peninsula. Jordan's geographic situation frightens many investors, since its neighbors include Syria, Iraq, Saudi Arabia, and Palestine. Jordan is located in a region inflamed by wars and conflicts, which negatively affects its economy. Jordan also has the longest borders with the land of Palestine that is occupied by the Israeli entity. The Israeli entity's occupation of the land of Palestine has caused many political and social problems in Jordan. This occupation is trying to affect the Jordanian economy in various ways to weaken it. Political tensions in the region badly affects the prospective investment climate of the country, and financial decision-makers don't always distinguish Jordan's investment climate from the instability surrounding it.

\section{J. Availability / Easiness to Import of Raw Materials}

Availability of raw materials means that international investors can do business in the country without having concerns for the supply of production materials. Jordan has substantial deposits of potash and phosphates, and smaller quantities of unrefined salt, copper ore, gypsum and manganese. But, the import export policy is quite friendly and liberal, which permits manufacturers to import those raw materials in to the country. Hence, under this determining factor, the country has nothing much to offer to attract FDI.

\section{K. Technology Adoption and Innovation}

Technology is an important consideration made by foreign investors because it determines the scope of operational efficiency. From an investment perspective, the lack of efficient technology systems implies that operations would be slow and costly, and, thus, there will be a need for choosing destinations with a higher level of technology. Table 15 gives the ranking for Jordan on ICT adoption during 2014 to 2019 based on mobile-cellular telephone subscriptions, mobilebroadband subscriptions, fixed broadband internet subscriptions, fiber internet subscriptions and internet users.

TABLE 15. ICT ADOPTION: RANKING OF JORDAN - 2014 TO 2019

\begin{tabular}{lcccccc}
\hline Year & 2014 & 2015 & 2016 & 2017 & 2018 & 2019 \\
\hline Global Rank & 73 & 76 & 75 & 67 & 75 & 82 \\
\hline
\end{tabular}

Source: Compiled from Global competitiveness reports 2013-2014 to 2019

In ICT adoption Jordan position is seen to be declining from rank 73 in 2014 to rank 82 in 2019 . Table 16 gives the ranking for Jordan on innovation friendliness during 2014 to 2019 based on diversity of workforce, state of cluster development, international co-inventions, multi-stakeholder collaboration, scientific publications, patent applications, R\&D expenditures, prominence of research institutions, buyer sophistication and applications made for trademark.

TABLE 16. INNOVATION CAPACITY: RANKING OF JORDAN

\begin{tabular}{lcccccc}
\hline Year & 2014 & 2015 & 2016 & 2017 & 2018 & 2019 \\
\hline Global Rank & 41 & 40 & 40 & 46 & 59 & 64 \\
\hline
\end{tabular}

Source: Compiled from Global competitiveness reports 2013-2014 to 2019

In innovation friendliness Jordan's position is seen to be dropping from rank 41 in 2014 to a low of rank 64 in 2019. Now let us look at the ranking of by Global Innovation Index [33], which ranks on criteria that includes institutions, human capital and research, infrastructure, credit, investment, linkages; the creation, absorption and diffusion of knowledge; and creative outputs. Table 17 gives the ranking of Jordan in the Global Innovation Index during 2014 to 2019.

TABLE 17. GLOBAL INNOVATION INDEX: JORDAN'S RANKING

\begin{tabular}{lcccccc}
\hline Year & 2014 & 2015 & 2016 & 2017 & 2018 & 2019 \\
\hline GII & 64 & 75 & 82 & 83 & 79 & 86 \\
\hline Innovation Inputs & 72 & 80 & 88 & 92 & 88 & 91 \\
\hline Innovation Outputs & 57 & 67 & 77 & 74 & 67 & 71 \\
\hline
\end{tabular}

Source: Compiled from the Global Innovation Index 2014 to 2019

Over the last six years, Jordan's ranking has deteriorated from rank 64 in 2014 to rank 86 in 2019. Its ranking in innovation inputs has declined from 72 in 2014 to 91 in 2019. 
Similarly, the innovation outputs have also declined from 57 in the year 2014 to 71 in the year 2019. The above data show that the position of Jordan is weakening in technology adoption and innovation, which deters FDI.

\section{Ease of Doing Business}

The World Bank Group's Doing Business Report ranks economies based on their ease of doing business. A high ease of doing business ranking means the regulatory environment is more conducive to the starting and operation of a local firm. Table 18 gives the ranking for Jordan from 2015 to 2020.

TABLE 18. EASE OF DOING BUSINESS: JORDAN'S RANKING

\begin{tabular}{lcccccc}
\hline Year & 2015 & 2016 & 2017 & 2018 & 2019 & 2020 \\
\hline Global Rank & 117 & 113 & 118 & 103 & 104 & 75 \\
\hline
\end{tabular}

Source: Compiled from the Doing Business Report 2015 to 2020

Jordan has implemented important economic reforms, vaulting it to 75th out of 190 economies in the Doing Business rankings for 2020, a significant improvement from last year's 104th ranking. The visible improvement was in the areas of getting credit, paying taxes and resolving insolvency. Access to credit was expanded after the credit bureau began offering credit scores to banks and other financial institutions. Jordan also strengthened access to credit by introducing a new secured transactions law that regulates functional equivalents to loans secured with movable property, such as financial leases and fiduciary transfer of title. Jordan made paying taxes easier by integrating labor taxes and other mandatory contributions into its electronic payment system. Jordan also adopted a new insolvency law that permits the continuation of the debtor's essential contracts during insolvency proceedings and allows the debtor to reject overly-burdensome contracts [34]. This is quite favoring, still more can be done to make Jordan more investment-friendly and attractive to FDIs.

\section{CONCLUSION}

The review of various factors shows that the attractiveness of Jordan as a FDI destination is declining. A number of global business indexes and global ranking agencies have acknowledged this by assigning lower ranks to Jordan against most of the determinants of FDI. The parameters making Jordan an unattractive destination are the small market, declining economic growth, insufficient infrastructure developments, deteriorated logistics performance, small labor force, relatively low labor market efficiency, high currency inconvertibility and transfer restriction risks, high degree of corruption, increasing income tax rates, frightening geographic location, political tensions in the region with the proximity of Iraq, Syria and Israel, limited raw materials deposits, low level of technology adoption and innovation. On the other hand, the factors that contribute in making it attractive are the lower corporate tax rates, high degree of political stability among the counties in the Middle East, low expropriation risk, lower interest rates, substantially strong financial system, and the significant improvement Jordan has made in ease of doing business during the last year, as a result of the initiatives taken by the government. Which shows that there is willingness on the part of the government to take necessary initiatives to make the environment investorfriendly. Hence, the investors may factor in these factors, both positive and negative, while making their investment decisions.

Limitations of this study is that the impact of current Novel Coronavirus COVID-19 is not factored into the study, as it is still an ongoing pandemic, hence the investors are requested to factor in that while making the investment decisions.

\section{REFERENCES}

[1] M. Fernandez, and R. Joseph, "Qatar emerging as the most attractive FDI destination in the GCC", International Journal of Economics and Finance, vol.8, no.11, pp.175-192, 2016.

[2] World Investment Report. (2019). Available: http://unctad.org/en/PublicationsLibrary/wir2019_en.pdf

[3] J. W. Cho, "Foreign direct investment: determinants, trends in flows and promotion policies", Investment Promotion and Enterprise Development Bulletin for Asia and the Pacific, vol.1, pp. 99-112, 2003.

[4] M.S. Oudat, A.A. Alsmadi, and N.M. Alrawashdeh, "Foreign direct investment and economic growth in Jordan: an empirical investigation using the cointegration limits test", Finance and Economic Policy Magazine, vol. 11, no. 1, pp. 55-63, 2019. Available: https://doi.org/10.14718/revfinanzpolitecon.2019.11.1.4

[5] A.A. Alsmadi, and M.S. Oudat, "The effect of foreign direct investment on financial development: Empirical evidence from Bahrain", Ekonomski Pregled, vol. 70 no. 1, pp. 22-40, 2019.

[6] S. Bhattacheryay, "Foreign direct investment in India opportunities and challenges". International Journal of Asian Business and Information Management, vol.9, no. 4, pp.1-20, 2018.

[7] OECD, "Main determinants of FDI and its impact of foreign direct investment on China's economy", working papers on international investment no. 4, prepared for OECD cooperation programme, 2000.

[8] P. Xaypanya, P. Rangkakulnuwat, and S.W. Paweenawat, "The determinants of foreign direct investment in ASEAN", International Journal of Social Economics, vol.42, no.3, pp. 239-250, 2015.

[9] A.Q. Khachoo, and M.I. Khan, "Determinants of FDI inflows to developing countries: a panel data analysis", 2012.

[10] R. Gedam, Determinants of FDI and India's experience: Economic Reforms in India, 2nd ed. Deep and Deep Publication, 1996, pp. 82 100 .

[11] F.R. Root, and A.A. Ahmed, "Empirical determinants of manufacturing direct foreign investment in developing countries", Economic Development and Cultural Change, vol. 27, no. 4, pp. 751$767,1979$.

[12] F. Schneider, and B.S. Frey, "Economic and political determinants of foreign direct investment", World Development, vol. 13, no. 2, pp. 161$175,1985$.

[13] C. Chopra, Foreign investment in India, 1st ed. Deep and Deep Publication, New Delhi, 2003, pp 34-45.

[14] Neumayer, Eric, and Indra, Soysa, "Trade openness, Foreign direct investment and Child labor", World Development, vol. 33, no. 1, pp. 43-63, 2005

[15] H.V. Milner, "Introduction: The global economy, FDI, and the regime for investment", World Politics, vol. 66, no.1, pp. 1-11, 2014.

[16] Global Competitiveness Report (2019). Available: https://www.weforum.org/reports/how-to-end-a-decade-of-lostproductivity growth.

[17] J.H. Dunning, "The determinants of international production", Oxford Economic Papers, vol. 25, no. 3, pp. 289-336, 1973.

[18] A. Chandalert, "The Determinants of U.S. direct investment in Thailand: A survey on managerial perspectives", Multinational Business Review, vol. 8 no. 2, pp. 82-88, 2000.

[19] Richard. E. Caves, "International corporations: The industrial economics of foreign investment", Economica, vol. 35 no. 141, pp. 1$27,1971$.

[20] H. Zhao, and G. Zhu, "Location factors and country-of-origin differences: An empirical analysis of FDI in China", Multinational Business Review, vol. 8, no. 1, pp. 60-73, 2000.

[21] WEF Report 2019. International Monetary Fund, World Economic Outlook Database, October 2019. Available: https://www.imf.org/external/pubs/ft/weo/2019/02/weodata/index.asp $\mathrm{X}$

[22] M. Obstfeld, and R. Duval, "Tight monetary policy is not the answer to weak productivity growth", $2018 . \quad$ Available: 
https://voxeu.org/article/tight-monetary-policy-not-answer-weakproductivity-growth.

[23] M. Fernandez, A.M. Shubaisi, and R. Joseph, "Examination of potentialities of Vietnam as FDI destination", Journal of Economics and Business, vol.3, no.3, pp. 980-994, 2020.

[24] Business and economic data for 200 countries. Available: https://www.theglobaleconomy.com/download-data.php.

[25] Logistics Performance Index, (2018). Available: http://lpi.worldbank.org/international/global

[26] Agility Emerging Markets Logistics Index (2020). Available: https://www.agility.com/insights/emerging-markets-logisticsindex/rankings/

[27] S. Brakman, and H. Garretsen, Foreign direct investment and the multinational enterprise, MIT Press, 2008.

[28] Credendo Group index reports. Available: https://www.credendo.com/country-risk

[29] Transparency International, the Corruption Perceptions Index. Available at: http://www.transparency.org

[30] The Central Bank of Jordan. Available: https://www.cbj.gov.jo/

[31] KPMG data.
https://home.kpmg/xx/en/home/services/tax/tax-tools-andresources/tax-rates-online/corporate-tax-rates-table.html

[32] KPMG data. Available:

https://home.kpmg/xx/en/home/services/tax/tax-tools-andresources/tax-rates-online/individual-income-tax-rates-table.html

[33] Global Innovation Index (2019). Available: https:/www.globalinnovationindex.org/content/page/data-analysis/

[34] Doing business global ranking (2020). Available: http://www.doingbusiness.org/rankings.

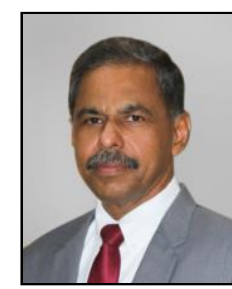

Dr. Manuel Fernandez is a professor in Finance and Accounting. He is a Certified Management Accountant (CMA) from the Institute of Management Accountants of the USA, Certified Cost Accountant (ACMA) from the Institute of Cost Accountants of India, and is Certified in Strategy and Competitive Analysis (CSCA) from the Institute of Management Accountants, USA. He has more than three decades of experience in teaching, research and academic administration.

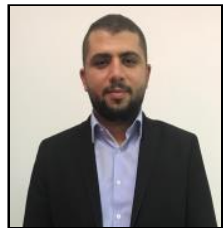

Odai Mohannad Suleiman is a scholar at Skyline University College, Sharjah, UAE. Procurement \& Inventory Accountant at Municipality \& Planning Department, Ajman, UAE.

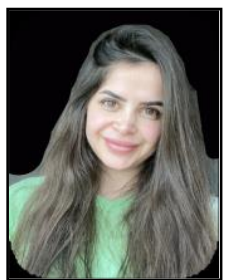

Sereen Najati Yaseen is a scholar at Skyline University College, Sharjah, UAE. Teacher at Sharjah American International School, UAE 